DOI: $10.33067 /$ SE.1.2021.4

Aleksandra Borowicz`

\title{
Does the New Industrial Strategy for Europe Follow the Path of the Concept of Industry 4.0?
}

\begin{abstract}
The concept of Industry 4.0 turns 10 years old in 2021. This milestone calls for renewed inquiries to review the current efforts of the European Union (EU) and its Member States towards the modernisation of European industry. In 2018, the European Commission published the Digital Transformation Scoreboard 2018: EU businesses go digital: Opportunities, outcomes and uptake, which reports on the readiness for the digital revolution focused on building an economy in line with the concept of Industry 4.0 at three levels: European, national, and business. This study shows how much still remains to be done. At the same time, it identifies some of the key elements contributing to the success in this area, i.e., the digitisation of machines, Big Data, robotics and artificial intelligence, which represent the very essence of the idea of revolution 4.0. The aim of the paper is to determine the extent to which the new strategy for industry proposed by the European Commission in 2020 follows the concept of Industry 4.0. Quantitative and qualitative research methods were used. Statistical analysis was used to demonstrate the importance of industry in the economy of the European Union between 1998 and 2019 in terms of the share in the added value created and the significance for the labour market. The descriptive methods used include a review of the literature and research on the concept of Industry 4.0 and an analysis of the latest strategic documents of the European Commission (EC) in relation to industrial policy.
\end{abstract}

Keywords: Industry 4.0, Industrial Policy, European Integration, Fourth Industrial Revolution

^Aleksandra Borowicz - University of Gdansk, e-mail: aleksandra.borowicz@ ug.edu.pl, ORCID: 0000-0001-6183-7902. 


\section{Introduction}

Since 2011, the year the concept of Industry 4.0 was introduced, a number of studies have explored and researched this issue. The concept incorporates robotics, Big Data, and state-of-the-art digitised process management in the enterprise. It has been pointed out that it is a natural course of industrial development in the era of such intense growth of information and communication technologies. ${ }^{1}$ Therefore, this term is interchangeably used when defining the so-called fourth industrial revolution.

The current climate is unique and offers a rationale for revisiting this issue and its broad analysis. This assertion stems from several facts, the first of which is that, the European Union in the latest 2020 European Innovation Scoreboard overtook the US, improving its score by 8.9 percentage points between 2012 and 2020. ${ }^{2}$ Secondly, a new European Commission headed by Ursula von der Leyen was appointed mid-year in 2019. Thirdly, work on the new shape of the Multiannual Financial Framework for 2021-2027 has intensified considerably. The fourth fact is that a large part of the strategic documents had to be prepared anew in this very context taking into account the challenges and changes taking place in the global economy and society. Lastly, the end of 2019, the whole of 2020 and most likely the next two years will have one common denominator - the pandemic. Thus, the European Union's actions must be comprehensive in nature, enabling the building of a stable and crisis-resilient economy. One of these areas that may, amidst all the challenges, serve as an instrument of recovery is industrial policy.

Industrial policy as a supporting competence is essential for the European economy and society. ${ }^{3}$ Despite the increasing servitisation of the economy, industry is still important in the EU in terms of creating added value and jobs. The nearly $19 \%$ share in added value creation and the maintenance of 36 million jobs are particularly important in view of

1 R. Davies, Industry 4.0. Digitalisation for productivity and growth, European Parliament, https://www.europarl.europa.eu/RegData/etudes/BRIE/2015/568337/EPRS BRI(2015)568337_EN.pdf (access 12.12.2020); L.M. Fonseca, Industry 4.0 and the digital society: concepts, dimensions and envisioned benefits, "Proceedings of the International Conference on Business Excellence", no. 1, vol. 12/2018, pp. 386-397.

2 S. Umiński, A. Borowicz, Will multinational enterprises contribute to Poland's economic resilience and recovery during and post COVID-19 pandemic, "Transnational Corporations Review” 2021, DOI: 10.1080/19186444.2021.1888638, p. 3.

3 Treaty on Functioning of European Union. Official Journal of European Union. C326/47. Brussels, 26.10.2012. 
the ongoing pandemic crisis. ${ }^{4}$ In 2018, the EC indicated in its "Digital Transformation Scoreboard 2018" that acceleration in this area is needed despite the progress made by Industry $4.0 .^{5}$ The aim of this paper is to determine the extent to which the new strategy for industry proposed by the European Commission in 2020 follows the concept of Industry 4.0. Given this, two research questions are posed:

- Is an active industrial policy needed in an era of progressive servitisation of the economy?

- Does the proposed by EC industrial strategy for the coming years correspond to the concept of Industry 4.0 ?

The following research methods will be applied in this paper: a systematic literature review aimed at presenting selected issues related to the concept of Industry 4.0; statistical data analysis using EUROSTAT data presenting the importance of industry in the European economy and the analysis of strategic documents of the European Commission in the area of industrial policy. On this basis, answers to the set research questions will be formulated.

\section{The Concept of Industry 4.0 - Literature Review}

The concept of Industry 4.0 was presented in Germany in 2011 at the Hannover Messe. Consequently, the literature suggests that the period from 2013 onwards should be referred to as the fourth technological revolution. The literature also pinpoints such features as digitalisation, automation, optimisation, personalisation, production customisation; human-machine interaction (HMI); value-added services and business; and automated data exchange and communication (ICT). ${ }^{6}$ The Industry 4.0 concept demonstrates the need to revise the existing business models towards selling services rather than goods, and to frequently change the services offered, which will lead to opportunities to generate additional income for innovative companies that meet these challenges. Beyond the strictly technological issue, the concept of Industry 4.0 points to the challenge of adapting the skills of the workforce to the

4 European Commission, A new Industrial Strategy for a globally competitive, green and digital Europe, Brussels, 10.03.2020, https://ec.europa.eu/commission/ presscorner/detail/en/fs_20_425 (access 10.02.2020).

5 European Commission, Digital Transformation Scoreboard 2018. EU Business Go Digital: Opportunities, Outcomes and Uptake. Luxembourg: Publications Office of the European Union, 2018, https://ec.europa.eu/growth/tools-databases/dem/ monitor/sites/default/files/Digital\%20Transformation\%20Scoreboard\%202018_0.pdf (access 26.02.2021).

6 L.M. Fonseca, op. cit. 
achievements of advanced technologies. The answer to this is to retrain these individuals. ${ }^{7}$

Industry 4.0 is a concept identified by researchers as a digitised factory that functions on the basis of smart-specialisation using technology and devices that autonomously communicate in the production process. ${ }^{8}$ The literature discussing and analysing the Industry 4.0 concept is quite diverse. A 2013 Acatech report describes Industry 4.0 drivers and benefits, but does not indicate any specific definition of Industry 4.0. ${ }^{9}$ Dalenogare et al. identifies the potential benefits of implementing specific elements into the industrial production process using regression analysis. ${ }^{10}$ In the literature, apart from studies aimed at identifying the benefits for industry related to the implementation of Industry 4.0 features, one can find analyses devoted to the readiness of individual economies to implement the cutting edge business model that is Industry 4.0. The Hungarian economy was analysed in 2019 and it showed that a significant proportion of the companies surveyed understand the need for change, but at the same time it was pointed out that companies implement these solutions only to a moderate extent. ${ }^{11}$ Grzelczak et al. assessed the preparedness of enterprises in Poland to implement the Industry 4.0 model, but in terms of the competencies held by employees. ${ }^{12}$ Another study evaluated the readiness of the industrial sector of the European Union in terms of digital infrastructure and the maturity of the economy to use Big Data to implement

7 R. Davies, op. cit.

8 M. Brettel, N. Friederichsen, M. Keller, M. Rosenberg, How Virtualization, Decentralization and Network Building Change the Manufacturing Landscape: An Industry 4.0 Perspective, World Academy of Science, Engineering and Technology, Open Science Index 85, "International Journal of Information and Communication Engineering”, no. 8(1)/2014, pp. 37-44; J. Smit, S. Kreuzter, C. Moeller, M. Carlberg, Industry 4.0. Analytical Study, European Parliament, 2016, February 19, 2021, https://www. europarl.europa.eu/RegData/etudes/STUD/2016/570007/IPOL_STU(2016)570007 EN.pdf (access 26.02.2021).

9 Recommendations for implementing the strategic initiative Industrie 4.0: Final report of the Industrie 4.0 Working Group, eds. H. Kagermann, W. Wahlster, J. Helbig, 2013, https:/www.din.de/blob/76902/e8cac883f42bf28536e7e8165993flfd/recommendations-for-implementing-industry-4-0-data.pdf (access 26.02.2021).

${ }^{10}$ L.S. Dalenogare, G.B. Benitez, N.F. Ayala, A.G. Frank, The expected contribution of Industry 4.0 technologies for industrial performance, "International Journal of Production Economics”, vol. 204/2018, pp. 383-394, DOI: 10.1016/j.ijpe.2018.08.019.

${ }^{11}$ G. Nick et al., Industry 4.0 readiness in Hungary: model, and the first results in connection to data application, "IFAC-PapersOnLine", no. 13, vo. 52/2019, pp. 289-294.

12 A. Grzelczak, M. Kosacka, K. Werner-Lewandowska, Employees Competences for Industry 4.0 In Poland - Preliminary Research Results, "DEStech Transactions on Engineering and Technology Research” 2018. 
the Industry 4.0 model and indicated the existence of 5 relatively homogeneous groups of countries that differed from one another. The authors thus conclude that the maturity of member states varies greatly. ${ }^{13}$

Industry 4.0 triggers major economic, social, and environmental changes, which was also highlighted at the World Economic Forum in Davos in 2016. Therefore, individual Member States, following in the footsteps of the pioneers, i.e. German companies and government, have introduced this concept into their strategies. In Italy, the so-called Factories of the Future (Fabricca del Futuro) were created. This was an initiative that had already been implemented between 2011 and 2013, which supported research initiatives in the areas of product customisation, factory modernisation, and high productivity using ICT. In France, on the other hand, a plan was launched in 2015 to also develop a Factory of the Future, which was a demonstration centre for new products and services. This scheme focused attention on the SME sector, which was offered the opportunity to benefit from loans worth $€ 1$ billion for projects related to robotics, digitisation and energy efficiency. France launched a total of 7 schemes grouped under the "Industry of the Future" concept. The United Kingdom (UK) implemented a number of programmes in connection with the execution of the Industry 4.0 concept, but the leading project were the so-called Catapult Centres, which had been receiving support since 2011. The support was directed at the establishment of centres equipped with highly advanced technological infrastructure. Today, there is a network of about 40 locations in the UK, consisting of socalled hubs, laboratories, test sites, factories and offices, as well as teams of experts who implement breakthrough products, processes, services and technologies in a variety of industries ${ }^{14}$ In Poland, in 2016, the idea of the Future Industry Platform was floated in the government's Strategy for Responsible Development, and a bill regarding the Platform was signed, which opened the way for it to move into the implementation stage. This tool is intended to support entrepreneurs in the process of transition and to serve as a kind of guide in the adjustment processes to the challenges of Industry 4.0, particularly in the area of staff training and the implementation of technological processes. ${ }^{15}$

13 I. Castelo-Branco, F. Cruz-Jesus, T. Oliveira, Assessing Industry 4.0 readiness in manufacturing: Evidence for the European Union, "Computers in Industry", no. 107/2019, pp. 22-32, DOI: https://doi.org/10.1016/j.compind.2019.01.007.

14 R. Davies, op. cit.

15 See more at: www.przemyslprzyszlosci.gov.pl. 


\section{Why Does the EU Need an Active Industrial Policy?}

Between 2010 and 2019, the share of industry in the generation of added value of the European economy decreased slightly. According to Eurostat data, in 2010, EU-28 industry share, excluding construction, stood at over 19.1\%, whereas in 2019 it went down to $18.8 \%$ (see Figure 1). Eurozone countries have seen an increase in the importance of industry in this category from $19.1 \%$ to $19.3 \%$, respectively. The group of countries noticing the rise of the industry contribution to value added between 2010 and 2018 includes Bulgaria, Ireland, Italy, Poland, Portugal, and Slovenia. The decline in industry share in the creation of added value has been apparent for quite some time. Eurostat reports that compared to 1998, this share has decreased by 3.8 percentage points (from $22.6 \%$ to $18.8 \%$ ).

Figure 1. The share of value added in the economy of EU28 and its Member States in 2010 and 2018 (\%)

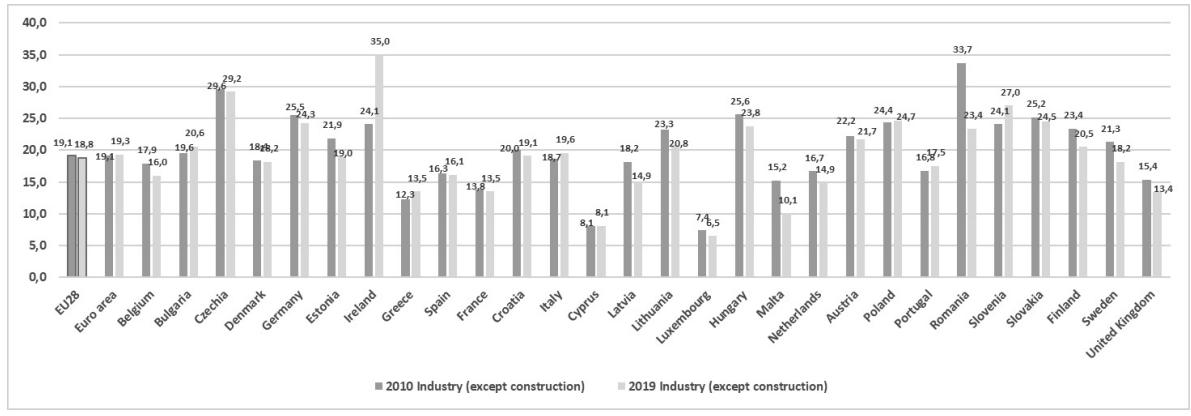

Source: own elaboration based on Eurostat database.

The share of industry in total employment in the European Union in 2019 amounted to $15.1 \%$. Compared to 1998, this represents a drop of more than 5 percentage points. Nevertheless, more than 36 million Europeans were employed in industry in 2019. The change in the number of employees and the share of industry in the employment structure for the Union as a whole and for individual Member States is due to a change in the structure of the economy, with a shift towards high-tech-based services. Economic growth itself also contributes to such phenomena as the off-shoring of parts of the labour-based production chain to countries with cheaper labour. Similarly, the progressive digitalisation and technological development of the economy is also significantly driving the above changes. ${ }^{16}$ Still, indus-

16 S. Houseman, C. Kurz, P. Lengermann, B. Mandel, Offshoring Bias in U.S. Manufacturing, "Journal of Economic Perspectives", no. 2, vol. 25/2011, pp. 111-132, 
try remains an important part of the economy, especially in new Member States. The reason for this is that the economies of these countries are still undergoing structural transformation and part of the industrial production has already been transferred from the EU member states to the then aspiring member states since the 1990 s. ${ }^{17}$ As many as $99 \%$ of enterprises in the European Union are small-and-medium-sized enterprises and industry generates up to $80 \%$ of EU exports. ${ }^{18}$

Figure 2. The contribution of industry to the overall employment of EU28 and Member States in 1998 and 2019 (\%).

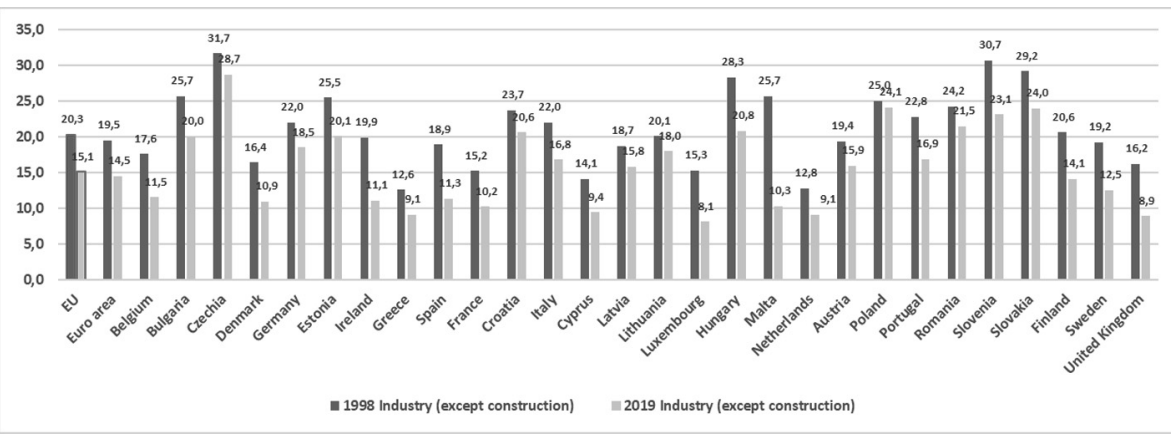

Source: own elaboration based on Eurostat database.

Industry in the contemporary world is affected by a couple of factors. Firstly, in the global economy, competition is based on innovation and advanced technologies. ${ }^{19}$ This process is compounded by the increasing

DOI: doi=10.1257/jep.25.2.111; U. Witt, C. Gross, The rise of the "service economy" in the second half of the twentieth century and its energetic contingencies, "Journal of Evolutionary Economics”, vol. 30/2020, pp. 231-246, https://doi.org/10.1007/s00191-01900649-4.

17 B. Dachs et al., Offshoring of Production - A European Perspective: Frequency, Target Regions and Motives, European Manufacturing Survey 2, "SMEs Bulletin" 2006, https://www.researchgate.net/profile/Steffen-Kinkel/publication/268075996_Offshoring_of_Production_-_A_European_Perspective_Frequency_Target_Regions and_Motives/links/54789fc80cf2a961e4877ba3/Offshoring-of-Production-A-European-Perspective-Frequency-Target-Regions-and-Motives.pdf (access 10.02.2021).

${ }_{18}$ European Commission, A new Industrial Strategy for a globally competitive, green and digital Europe, Brussels, 2020, Retrieved from https://ec.europa.eu/commission/ presscorner/detail/en/fs_20_425 (access 10.02.2021).

${ }_{19}$ P. Aghion, P. Howitt, $A$ Model of Growth Through Creative Destruction, "Econometrica", no. 2, vol. 60/1992, p. 323, DOI:10.3386/w3223; J. Bughin et al., Innovation in Europe. Changing the game to regain a competitive edge (Discussion Paper), 2019, https://www.mckinsey.com/ /media/mckinsey/featured\%20insights/innovation/reviving\%20innovation\%20in\%20europe/mgi-innovation-in-europe-discussion-paper- 
digitalisation of the economy and society, as highlighted in particular by the outbreak of the COVID-19 pandemic in 2019. ${ }^{20}$ Last but not least, a particularly costly aspect of the changes taking place in the industrial sector is the European Union's move towards a climate-neutral economy, which requires an ecological transition.

The pandemic outbreak has demonstrated that home-grown European industry is extraordinarily important as a guarantee of both security of supply and socio-economic stability. Intense economic interdependence in the form of deepening economic integration is the main driver of economic growth in the European Union. The dispersed global supply chains that have been operating for a year in the pandemic reality are still encountering problems with the supply of intermediate and finished products. It seems that the process of rebuilding an economy resistant to economic shocks must inevitably involve an effectively functioning internal market, which gives European industrial businesses the opportunity to develop and establish a competitive position on global markets.

\section{The Industrial Policy of the European Union - Its Origin and Evolution}

Together with science and technology policy or entrepreneurship policy, industrial policy represents one of those areas which are of particular significance for ensuring economic freedom in the EU. It is precisely the industrial policy that is coordinated at the Community level using the instruments of positive integration. The coordination of economic policies, industrial policy among them, serves in the EU as a means of responding to emerging inefficiencies at the state level and supports economic actors in taking full advantage of the common market. ${ }^{21}$ The Treaty of Lisbon introduced the industrial policy among the supporting competences,

oct2019-vf.pdf (access: 10.02.2021); P. Moncada-Paternò-Castello, H. Hernandez, Ten-year evolution of EU industrial RED in the global context, "JRC Policy Insights", No. JRC112352/2018.

20 F. Almeida, J. Duarte Santos, A. Monteiro, The Challenges and Opportunities in the Digitalization of Companies in a Post-COVID-19 World, "IEEE Engineering Management Review”, no. 3, vol. 48/2020, pp. 97-103, DOI: https://doi.org/10.1109/ EMR.2020.3013206; S.J. Barnes, Information management research and practice in the post-COVID-19 world, "International Journal of Information Management", vol. 55/2020, p. 102175, DOI: https://dx.doi.org/10.1016\%2Fj.ijinfomgt.2020.102175.

${ }^{21}$ K. Gawlikowska-Hueckel, A. Zielińska-Głębocka, Integracja europejska. Od jednolitego rynku do unii walutowej, Warsaw 2004, p. 156. 
meaning that the role of EU is to provide assistance towards the actions of Member States. ${ }^{22}$ At the same time, EU institutions have always been engaged in establishing a framework to support the industry of the EU, especially in the context of global competition.

The legislative basis for fostering the industrial policy was already established in the Single European Act underlying the need to strengthen the scientific and innovative potential for the purpose of international competitiveness. ${ }^{23}$

According to Article 173 TFEU, EU industrial policy shall be aimed at:

„1) speeding up the adjustment of industry to structural changes;

2) encouraging an environment favourable to initiative and to the development of undertakings throughout the Union, particularly small and medium-sized undertakings;

3) encouraging an environment favourable to cooperation between undertakings

4) fostering better exploitation of the industrial potential of policies of innovation, research and technological development."

In the 1990s, with the imminent completion of the establishment of the internal market, the industrial strategy was revolutionised towards reliance on a liberal approach, free competition and structural change as opposed to the 1970s when a protectionist approach was dominant. ${ }^{24}$ During this period, priorities included supporting scientific research, technological development and fostering industrial cooperation, including a global market presence. An important factor shaping the growing involvement of the EC in the implementation of industrial policy was also the construction of the EMU and subsequent EU enlargements. The objectives set for Member States in the Lisbon Strategy of 2000 led the EC to present an integrated approach to Community actions in the field of industrial policy in the mid-2000s. The policy itself evolved towards the implementation of sustainable consumption and production, with priority given to improving the competitiveness of European industry. Since then a number of initiatives have been launched, including the Raw Materials Initiative and measures to facilitate labelling. The EC, in its communications, emphasised the need to build a long-term strategy, including the development and implementation of key technologies. From

${ }^{22}$ Treaty on Functioning of European Union, op. cit.

23 European Community. Single European Act. Official Journal of the European Communities. No L 1691987. https://eur-lex.europa.eu/resource.html?uri= cellar:a519205f-924a-4978-96a2-b9af8a598b85.0004.02/DOC_1\&format $=$ PDF (access 10.02.2021).

${ }^{24}$ A. Zielińska-Głębocka, Wprowadzenie do ekonomii międzynarodowej, Gdańsk 1998. 
2010 onwards, the EC's initiatives were a consequence of the Europe 2020 Strategy adopted in 2010, with 4 initiatives fostering the competitiveness of European industry: ${ }^{25}$

1) the Innovation Union;

2) a digital agenda for Europe;

3) an integrated industrial policy for the globalisation era;

4) an agenda for new skills and jobs.

The subsequent years brought about updates and additions aimed at increasing the effectiveness of the measures adopted at the European level. However, it is worth noting that in 2016, in terms of improving the competitiveness of European industry, the EC put two main issues at the forefront, i.e., digitalisation and the single market, which, when combined, will prove essential for the development of European industry. Major support was given to start-ups and scale-ups to create an environment for them to develop their potential in the global market. ${ }^{26}$

\section{The Strategy for European Industry for the Next Decade}

The European Commission's efforts after 2020 are in line with the EC's priorities for 2019-2024, but also result from the newly adopted Multiannual Financial Framework for 2021-2027. As mentioned earlier, the industrial policy is also intended to contribute to making Europe a climateneutral continent. This comes across very clearly in the EC's areas of action as regards industrial policy. On the eve of the announcement of the lockdown caused by the outbreak of the coronavirus pandemic, i.e., on 10th March 2020, the Commission announced a New Industrial Strategy for Europe, which focuses on three key components: shaping competitive industry on a global scale, support for industries contributing to climate neutrality in Europe, and the digital transition of industry. ${ }^{27}$

These three fundamental areas are intended to penetrate into the specific measures implemented and proposed at the EU level. In its strategy, the European Commission pointed out that it is thanks to the single

25 European Commission, Communication from the Commission. Europe 2020. A European strategy for smart, sustainable and inclusive growth. Brussels, https:// ec.europa.eu/eu2020/pdf/COMPLET\%20EN\%20BARROSO\%20\%20\%20007\%20 -\%20Europe\%202020\%20-\%20EN\%20version.pdf (access 5.12.2020).

${ }^{26}$ See more: European Parliament, Ogólne zasady unijnej polityki przemysłowej, https://www.europarl.europa.eu/factsheets/pl/sheet/61/vseobecne-zasady-priemyselnej-politiky-eu (access 1.02.2021).

27 European Commission, European Industrial Strategy, 2020, https://ec.europa. eu/info/strategy/priorities-2019-2024/europe-fit-digital-age/european-industrialstrategy_en (access 1.02.2021). 
market that European businesses have a large internal market at their disposal, which enables trade to develop dynamically. As much as $80 \%$ of business exports in the EU go to Member States in the form of so-called intra-community trade. Industry in the EU accounts for $20 \%$ of added value. Moreover, it has been estimated that a deepened and more integrated single market with a competition policy responding to the challenges of the modern economy could contribute to an increase in EU GDP of $12 \%$. Nurturing and sound competition rules aim to protect the interests of European companies, enhance their ability to compete internationally and create an internal market that will become more attractive to companies from third countries. ${ }^{28}$ Direct support to SMEs, which make up $99 \%$ of businesses in the EU, is also a building block. They are the ones that create 2 out of 3 jobs, generate 50\% of the EU's GDP and about $50 \%$ of them are engaged in innovative activities. They require direct support, as only $17 \%$ use ICT in their manufacturing and service provision processes (compared to $54 \%$ of large enterprises), which is why the EU is promising to increase access to finance by launching the ESCALAR initiative to support the venture capital market, particularly interested in high-growth and risky ventures. ${ }^{29}$

\section{Scheme 1. The main areas of active policy in "A new Industrial Strategy} for green and digital Europe"
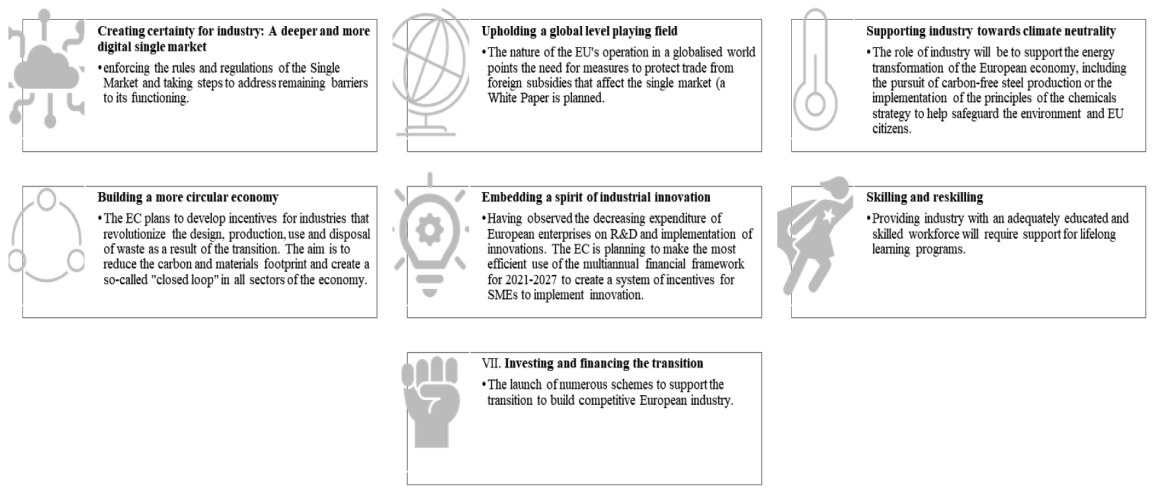

Source: author's own elaboration on the basis of "A new Industrial Strategy for green and digital Europe", European Commission 2020.

28 European Commission, A new Industrial Strategy for a globally competitive, green and digital Europe, Brussels 2020, https://ec.europa.eu/commission/presscorner/detail/en/fs_20_425 (access 1.02.2021).

29 European Commission, Unleashing the full potential of European SMEs, Brussels 2020, https://ec.europa.eu/commission/presscorner/detail/en/fs_20_426 (access 10.02.2021). 
These three cutting edge issues under the framework of the "A new Industrial Strategy for a green and digital Europe" enabled the European Commission to identify the seven thematic areas, which are briefly presented in Scheme 1.

The following main areas for undertaking the active policy are: ${ }^{30}$

\section{Creating certainty for industry: A deeper and more digital single market}

These will involve Commission activities aimed at enforcing the rules and regulations of the Single Market and taking steps to address the remaining barriers to its functioning, in particular with regard to corporate taxation. In this area, the EC points to the need to strengthen the cooperation between young, innovative SMEs and established SMEs in adapting their business models to the challenges of the digital era. In order to fully exploit the benefits of the single market, the EC points to the need for the EU to engage in the work of international standardisation bodies and to take action to protect EU intellectual property. As far as the competition policy is concerned, a review of principles was announced, which are to be adapted to the current challenges, also in the area of new state aid rules regarding fields such as energy and environmental aid, which are to come into force as of 2021.

\section{Upholding a globally level playing field}

The nature of the EU's operation in a globalised world points to the need for measures to protect trade from foreign subsidies that affect the single market (a White Paper is planned). In response to the symmetry in access to public procurement markets, the EC proposes the creation of an international public procurement instrument that will level the playing field in an international context. It is necessary to strengthen the functioning of the customs union, including the emphasis on digital customs clearance at the border and the enforcement of bilateral trade agreements.

30 European Commission, Communication from the Commission to the European Parliament, the European council, the council, the European Economic and Social Committee and the Committee of the Regions. A New Industrial Strategy for Europe: European Commission, $\operatorname{COM(2020)} 102$ final, https://eur-lex.europa.eu/legal-content/EN/TXT/?uri =CELEX:52020DC0102 (access 10.02.2021). 


\section{Supporting industry towards climate neutrality}

The role of industry will be to support the energy transformation of the European economy, including the pursuit of carbon-free steel production or the implementation of the principles of the chemicals strategy to help safeguard the environment and EU citizens. The Act establishing a new mechanism for equitable transition offers an opportunity to support regions highly reliant on coal during the process of transforming their industry and economy with approximately EUR 100 billion. The EC puts emphasis on smart cross-sectoral integration (combining sustainable actions within different sectors: electricity, gas, and liquid fuels), smart transport mobility and mechanisms for adjusting prices at borders in relation to $\mathrm{CO} 2$ emissions.

\section{Building a more circular economy}

The EC plans to develop incentives for industries that revolutionise the design, production, use and disposal of waste as a result of the transition. The aim is to reduce the carbon and material footprint and create a socalled "closed loop" in all sectors of the economy.

\section{Embedding a spirit of industrial innovation}

Having observed the decreasing expenditure of European enterprises on $\mathrm{R} \& \mathrm{D}$ and implementation of innovations. The EC is planning to make the most efficient use of the multiannual financial framework for 20212027 to create a system of incentives for SMEs to implement innovation. Public-private partnerships supporting publicly and privately-funded investments will be of critical importance.

\section{Skilling and reskilling}

Providing industry with an adequately educated and skilled workforce will require support for lifelong learning programs. Digitisation and the development of artificial intelligence will create a need for digital professionals. It is already estimated today that there are approx. 1 million vacancies for such experts and a significant number of companies are postponing their investment decisions due to problems with recruiting personnel.

\section{Investing and financing the transition}

The launch of numerous schemes to support the transition such as: Horizon Europe, Digital Europe, the Single Market Programme, the Innovation Fund, InvestEU, the European Social Fund, the European Defence 
Fund and the European Union Space Programme, as well as the European Structural and Investment Funds will be crucial in the process of building a competitive European industry.

\section{Conclusions: The Challenge for the EU: Is the European Union Moving Towards an Industry 4.0 Model Incorporating a New Strategy for Industry?}

The concept of Industry 4.0 is based on the use of smart systems that are connected to other business processes as a result of networking, which requires a combination of a selection of IT engineering and business management components. ${ }^{31}$ Harnessing technological advances, particularly in IT (information technology) to create so-called smart systems presents a challenge for businesses.

In its new strategy for industry, the European Union sets out 3 key ingredients to support European industry in creating added value and sustainable jobs. This vision is to be achieved by:

1) an energy transition in the industrial sector so that the EU achieves climate neutrality in 2050;

2) boosting single market efficiency to create an environment for highly competitive companies that fully benefit from the EU's internal market of around 450 million consumers (excluding the UK);

3) a digital transition and the implementation of advanced business models taking advantage of the progressive digitisation of the economy.

It seems that the measures introduced by the European Commission are intended to encourage entrepreneurs to take action so as to implement new business models that will increase their efficiency and innovativeness. In the long term, this may contribute to achieving competitiveness in the international arena. The EU industrial strategy which aims to improve the effectiveness of the common market shall be treated as the framework for further sustainable development of the EU, as it covers actions towards SMEs, green and digital Europe and single market. The industry in the new global settings will meet the challenge to incorporate the idea of digitalisation and servitisation of the production process. ${ }^{32}$

31 M. Götz, J. Gracel, Przemyst czwartej generacji (industry 4.0) - wyzwania dla badań w kontekście międzynarodowym, "Kwartalnik Naukowy Uczelni Vistula”, no. 1(51)/2017, pp. 217-235, http://cejsh.icm.edu.pl/cejsh/element/bwmetal.element. desklight-237b8clc-ff6c-48ed-b4ef-dd8fdc7f3397 (access 12.02.2021).

32 C. Santos et al., Towards Industry 4.0: an overview of European strategic roadmaps, "Procedia Manufacturing", vol. 13/2017, pp. 972-979, https://doi.org/10.1016/j. promfg.2017.09.093. 
The strategy for industry in the European Union itself does not seem to reflect all the assumptions of the so-called 4th Industrial Revolution, as the use of digitalisation alone in industry may prove to be insufficient. On the other hand, given the relative recentness of the European Commission (established in the second half of 2019), one should be hopeful about the future and further EU initiatives. The findings of this review of strategic documents and the analysis of statistical data confirm that, within the framework of industrial policy, the European Union shall be treated as an enabling organisation and one which creates some favourable conditions, but it is at the level of the Member States that the groundwork must take place. Despite the inherent limitations of this study, it is important to emphasise that the paper combines an analysis of recent European Union policy documents and of the key issue for the future development of the European economy, which is the concept of Industry 4.0. Given the studies selected, future research needs to draw on a wider number of European Commission publications in order to evaluate activities in this area at the European level.

\section{References}

Aghion P., Howitt P., A Model of Growth Through Creative Destruction, "Econometrica", no. 2, vol. 60/1992, DOI: https://doi.org/10.3386/ w3223.

Almeida F., Duarte Santos J., Augusto Monteiro J., The Challenges and Opportunities in the Digitalization of Companies in a Post-COVID-19 World, "IEEE Engineering Management Review", no. 3, vol. 48/2020, DOI: https://doi.org/10.1109/EMR.2020.3013206.

Barnes S.J., Information management research and practice in the post-COVID-19 world, "International Journal of Information Management", vol. 55/2020, DOI: https://doi.org/10.1016/j.ijinfomgt.2020.102175.

Brettel M. et al., How Virtualization, Decentralization and Network Building Change the Manufacturing Landscape: An Industry 4.0 Perspective, "International Journal of Information and Communication Engineering", no. 8(1)/2014.

Bughin E. et al., Innovation in Europe. Changing the game to regain a competitive edge (Discussion Paper), 2019, https://www.mckinsey.com/ / media/mckinsey/featured\%20insights/innovation/reviving\%20innovation\%20in\%20urope/mgi-innovation-in-europe-discussion-paperoct2019-vf.pdf (access 10.02.2021).

Castelo-Branco I., Cruz-Jesus F., Oliveira T., Assessing Industry 4.0 readiness in manufacturing: Evidence for the European Union, "Computers in Industry", no. 107/2019, DOI: https://doi.org/10.1016/j.compind.2019.01.007. 
Dachs B. et al., Offshoring of Production - A European Perspective: Frequency, Target Regions and Motives, European Manufacturing Survey 2. "SMEs Bulletin" 2006, https://www.researchgate.net/profile/SteffenKinkel/publication/268075996_Offshoring_of_Production_-_A_European_Perspective_Frequency_Target_Regions_and_Motives/ links/54789fc80cf2a961e4877ba3/Offshoring-of-Production-A-European-Perspective-Frequency-Target-Regions-and-Motives.pdf (access 25.01.2021).

Dalenogare L.S. et al., The expected contribution of Industry 4.0 technologies for industrial performance, "International Journal of Production Economics”, vol. 204/2018, DOI: https://doi.org/10.1016/j.ijpe.2018.08.019.

Davies R., Industry 4.0., Digitalisation for productivity and growth, European Parliament, 2015, https://www.europarl.europa.eu/RegData/ etudes/BRIE/2015/568337/EPRS_BRI(2015)568337_EN.pdf (access 10.12.2020).

European Commission, A new Industrial Strategy for a globally competitive, green and digital Europe, Brussels, 2020, https:/ec.europa.eu/ commission/presscorner/detail/en/fs_20_425 (access 1.02.2021).

European Commission, Communication From The Commission To The European Parliament, The European Council, The Council, The European Economic And Social Committee And The Committee Of The Regions. A New Industrial Strategy for Europe: European Commission, $\operatorname{COM}(2020) 102$ final, https://eur-lex.europa.eu/legal-content/ EN/TXT/?uri $=$ CELEX:52020DC0102 (access 10.02.2021).

European Commission, Communication from the Commission. Europe 2020. A European strategy for smart, sustainable and inclusive growth, Brussels 2010, https://ec.europa.eu/eu2020/pdf/COMPLET\%20EN\% 20BARROSO\%20\%20\%20007\%20-\%20Europe\%202020\%20-\%20 EN\%20version.pdf (access 5.12.2020).

European Commission, Digital Transformation Scoreboard 2018. EU Business Go Digital: Opportunities, Outcomes and Uptake. Luxembourg: Publications Office of the European Union, 2018, https://ec.europa. eu/growth/tools-databases/dem/monitor/sites/default/files/Digital\%20 Transformation\%20Scoreboard\%202018_0.pdf (access 26.02.2021).

European Commission, Unleashing the full potential of European SMEs, Brussels 2020, https://ec.europa.eu/commission/presscorner/detail/en/ fs_20_426 (access 10.02.2021).

European Community, Single European Act: Official Journal of the European Communities, 1987, https://eur-lex.europa.eu/resource. html?uri = cellar:a519205f-924a-4978-96a2-b9af8a598b85.0004.02/ DOC_1\&format $=$ PDF (access 1.02.2021). 
European Parliament, Ogólne zasady unijnej polityki przemysłowej, https://www.europarl.europa.eu/factsheets/pl/sheet/61/vseobecne-zasady-priemyselnej-politiky-eu (access 1.02.2021).

Fonseca, L. M., Industry 4.0 and the digital society: concepts, dimensions and envisioned benefits, "Proceedings of the International Conference on Business Excellence”, no. 1, vol. 12/2018, DOI: https://doi.org/10.2478/ picbe-2018-0034.

Gawlikowska-Hueckel K.,Zielińska-Głębocka A., Integracja europejska. Od jednolitego rynku do unii walutowej, Academia Oeconomica C. H. Beck, Warsaw 2004.

Götz M., Gracel J.,Przemyst czwartejgeneracji (industry 4.0)-wyzwania dla badań w kontekście międzynarodowym, "Kwartalnik Naukowy Uczelni Vistula", no. 1(51)/2017, http://cejsh.icm.edu.pl/cejsh/element/bwmetal.element. desklight-237b8clc-ff6c-48ed-b4ef-dd8fdc7f3397 (access 12.02.2021).

Grzelczak A., Kosacka M., Werner-Lewandowska K., Employees Competences for Industry 4.0 In Poland - Preliminary Research Results, "DEStech Transactions on Engineering and Technology Research", 2018, DOI: https://doi.org/10.12783/dtetr/icpr2017/17598.

Houseman S. et al., Offshoring Bias in U.S. Manufacturing, "Journal of Economic Perspectives", no. 2, vol. 25/2011, DOI: https://doi.org/10.1257/ jep.25.2.111.

Moncada-Paternò-Castello P., Hernandez H., Ten-year evolution of EU industrial REDD in the global context, "JRC Policy Insights", no. JRC112352/ 2018.

Nick G. et al., Industry 4.0 readiness in Hungary: model, and the first results in connection to data application, IFAC-PapersOnLine", no. 13, vol. 52/2019, DOI: https://doi.org/10.1016/j.ifacol.2019.11.185.

Recommendations for implementing the strategic initiative Industrie 4.0: Final report of the Industrie 4.0 Working Group, eds. H. Kagermann, W. Wahlster, J. Helbig, 2013, https://www.din.de/blob/76902/e8cac883f42b$\mathrm{f} 28536 \mathrm{e} 7 \mathrm{e} 8165993 \mathrm{flfd} / \mathrm{recommendations-for-implementing-industry-}$ 4-0-data.pdf (access 5.01.2021).

Santos C et al., Towards Industry 4.0: an overview of European strategic roadmaps, "Procedia Manufacturing", vol. 13/2017, DOI: https://doi. org/10.1016/j.promfg.2017.09.093.

Smit J., Kreuzter S., Moeller C., Carlberg M., Industry 4.0. Analytical Study, European Parliament, 2016, https://www.europarl.europa.eu/RegData/ etudes/STUD/2016/570007/IPOL_STU(2016)570007_EN.pdf (access 19.02.2021).

Treaty on Functioning of European Union. Official Journal of European Union. C326/47. Brussels, 26.10.2012. 
Umiński S., Borowicz A., Will multinational enterprises contribute to Poland's economic resilience and recovery during and post COVID-19 pandemic, “Transnational Corporations Review", 2021, DOI: https://doi.org/10. 1080/19186444.2021.1888638.

Witt U., Gross C., The rise of the "service economy" in the second half of the twentieth century and its energetic contingencies, "Journal of Evolutionary Economics", no. 2, vol. 30/2020, DOI: https://doi.org/10.1007/s00191019-00649-4.

Zielińska-Głębocka A., Wprowadzenie do ekonomii międzynarodowej, Wydawnictwo Uniwersytetu Gdańskiego, Gdańsk 1998. 